\title{
Self-evaluation of Parental Competence - Differences Between Parents with Pedagogical and Non-Pedagogical Professions
}

\author{
Anita Mandarić Vukušićc ${ }^{*}$ \\ ${ }^{1}$ Faculty of Social Sciences and Humanities, University of Split, Croatia \\ *Correspondence: Faculty of Social Sciences and Humanities, University of Split, Poljička cesta 35, 21000 Split, \\ Croatia. E-mail: amandari@ffst.hr
}

Received: January 26, 2018

Accepted: February 27, $2018 \quad$ Online Published: March 21, 2018

doi:10.5430/wje.v8n2p1

URL: https://doi.org/10.5430/wje.v8n2p1

\begin{abstract}
Parental competence is closely related to various factors, which can directly or indirectly influence parental behaviour. One of these factors is the level of education, and more recent research show that the parents' choice of profession can be favourable for the development of certain parental skills and experience of parental competence. The aim of this research was to determine if there is a difference in the sense of parental competence among parents of pedagogical professions. Research was conducted on a sample of 544 parents of pedagogical $(\mathrm{N}=247)$ and non-pedagogical professions $(\mathrm{N}=297)$. The results show that parents of pedagogical professions (kindergarten and elementary school teachers), more so than parents of other professions, estimate their parental Efficacy as better, but that is not the case with Satisfaction. This result can serve as confirmation to previous research about the positive connection between pedagogical and parental competence, and can contribute to understanding the connection of some pedagogical skills and abilities necessary for the development of parental competence.
\end{abstract}

Keywords: parental satisfaction and efficacy, kindergarten teacher, elementary school and class teacher, pedagogical education, profession

\section{Introduction}

Competency can be described as "a construct that represents a constellation of the characteristics of the person that result in effective performance in his or her job" (Kurz \& Bartram, 2002, p. 230). Competence "is about the application of knowledge and skills, judged in relation to some standard or set of performance standards" (Kurz \& Bartram, 2002, p. 235) while competencies "relate to the behaviours underpinning successful performance, what it is people do in order to meet their objectives; how they go about achieving the required outcomes; what enables their competent performance" (Kurz \& Bartram, 2002, p.235).

In this paper, we are not examining the state of parental competence because that type of examination would require a completely different approach to the research. Rather we are focused to determine the behavioural repertories that parents see in their parental behaviour. One of the most used instruments in determining parental sense of competence is the one by Johnston and Mash (1989), and that was the instrument used to find out if parents feel (un)satisfied and (in)effective in their role.

Parenting includes a number of parental activities, duties and behaviours directed toward care, protection, nurturing and child rearing (Čudina-Obradović \& Obradović, 2006). It is a feeling that can be simultaneously satisfying and stressful. The feeling of satisfaction will depend on the extent of which a parent is satisfied with their relationship with the child and their own parental role (Sabatelli \& Waldron, 1995; Waldron-Hennessey \& Sabatelli, 1997). It can be described as a feeling of affinity for that role, fulfilment and reward, as opposed to a feeling of dissatisfaction characterized by a sense of manipulation, imposing of excessive control and frustration. Satisfaction will depend on the parental assessment of the child's behaviour. If a parent estimates that the changes in the child's development are consistent with their relationship with the child, parenting satisfaction will be greater (Lacković-Grgin, 2011). Conversely, a feeling of dissatisfaction and stress can affect the parent's sense of burden by the parental role, which can ultimately reflect on the creation of hindering circumstances in the family environment (Crnic, Gaze \& Hoffman, 
2005). Such dissatisfaction and stress by the parental role can affect the reduced parental efficacy, while satisfaction will be positively associated with the experience of efficacy (Johnston \& Mash, 1989; Rogers \& Matthews, 2004).

Because the experience of satisfaction is related to the experience of achievement, security and control over the challenges of parenting, it is often terminologically related to efficacy, which can be the source of different approaches to research of parental competence (Reić Ercegovac, 2011) or it is often identified with parental competence even though it is considered to be only one of its aspects (Gilmore \& Cuskelly, 2008).

Parental efficacy can be defined as an experience of one's own ability to solve everyday challenges in child rearing (Johnston \& Mash, 1989; Sabatelli \& Waldron, 1995; Waldron-Hennessey \& Sabatelli, 1997). By assessing parental efficacy we can measure the degree in which a parent feels confident in their own parental role (Gilmore \& Cuskelly, 2008). Parents who feel confident in their own behaviours and trust their own capabilities will be more motivated to meet the expectations (Johnston \& Mash, 1989). In the experience of control over the challenges of parenting, it is important that parents set realistic child development expectations.

A person who is certain that they have control over the situation will be more focused on solving the problem (Crnic et al., 2005; Hawk \& Holden, 2006; Laskey \& Cartwright-Hatton, 2009). A parent who is in control of their behaviour and controls the situation is focused on constructive problem solving and will thus encourage the child's development in a proper and positive way (Gilmore \& Cuskelly, 2008). By contrast, parents who evaluate themselves as ineffective are often worse in communicating, controlling, and disciplining their child. Such approach leads to poorer development of children's social skills and, in the long-term, their relationships with peers (Secer, Gülay Ogelman, Önder \& Berengel, 2012).

Considering the fact that child rearing is multi-determined (Belsky, 1984; 2008; Bronfenbrenner, 1978, quoted in Bennett \& Grimley, 2001), it cannot be argued that the effects of child development are solely determined by effective parental activity (Ramaekers \& Suissa, 2012; Smith, 2010). But understanding the determinants and differentiating those that a parent can influence from those they cannot, can contribute to the development of personal competencies and resources that parents need in order to expand their life roles, as well as parental and family roles (Gorgievski \& Hobfoll, 2008; Gradney \& Cropanzano, 1999).

One of the important features of the modern age is the growing need for individuals to equally realize their potential in the workplace, but also their parental and family roles. Satisfaction and efficacy in the parental role can also be discussed while taking into consideration the fact that certain professions can have a "more favourable" effect on parenting or can contribute to expanding resources (Stevanovic \& Rupert, 2009; Feji et al., 1995, quoted in Taris, 1999). On one hand it is possible to assume that the degree of education is connected to the higher level of knowledge about parenting, namely the knowledge about child development and the environment needed to stimulate it (Morawska, Winter \& Sanders 2008). On the other hand, type of education can reflect on the development of professional and personal competencies. When investigating the correlation between the type of profession and family role satisfaction, a high level of family role satisfaction was established among psychotherapists and social workers (Lambert, Pasupuleti, Cluse-Tolar, Jennings, \& Baker, 2006; Stevanovic \& Rupert, 2009). Because of their job requirements, members of such professions increasingly use skills such as quality communication, compassion and understanding, and these are the skills that help them communicate with their family members, create a positive home atmosphere, solve family problems, and, in general, deal with the parenting role. In accordance to this it can be assumed that, in addition to the level of education, the profession of the parents can also reflect on how they experience their own parental role and parental behaviour. Bearing in mind that under the influence of educational spillover (Crouter, 1984; Stevanovic \& Rupert, 2009), development of skills necessary to carry out the professional role can be helpful in other life roles. It is possible to assume that parents whose professions require the development and implementation of pedagogical competencies in the workplace, will help those individuals positively experience their parental role. Therefore, the aim of this paper is to determine whether there is a difference in the experience of parental competence among parents of pedagogical professions. With this in mind, the main hypothesis (Hg) was: there is no statistically significant difference in the parenting sense of competence between parents of pedagogical and non-pedagogical professions. Sub-hypotheses were established as well (H1): there is no statistically significant difference in self-assessment of parental satisfaction between parents of pedagogical and non-pedagogical professions and $(\mathrm{H} 2)$ : there is no statistically significant difference in self-assessment of parental efficacy between parents of pedagogical and non-pedagogical professions. 


\section{Methods}

\subsection{Participants and Research Process}

The research was conducted on a sample of 544 parents of children aged between three and seven years. The sample consisted of 247 parents of pedagogical professions (kindergarten teachers, elementary school and subject teachers, pedagogues) and 297 parents of other professions (construction workers, engineers, economists, attorneys, health workers). All parents were highly educated (undergraduate degree $29.4 \%$, graduate degree $59 \%$ or academic degree $11.6 \%$ ). Although the majority of respondents, on average, had two children $(56.8 \%)$, for most of the respondents, a child between the age of three and seven was their first (57\%) or second child (31.2\%), while it was the third child among only $11.8 \%$ of families. Both sexes of children are nearly equally represented in this research as there are $52.8 \%$ of girls and $47.2 \%$ of boys. Most parents (92.5\%) spent from one to three hours or more per day with their children. In $67.8 \%$ cases, parents received support from wider family members several times per month. For the purpose of this research, a parental profession analysis was conducted. The results are shown in Table 1.

Table 1. Distribution of Respondents Based on non(Pedagogical) Professions

\begin{tabular}{|c|c|c|c|}
\hline Professions & $\mathrm{f}$ & $\%$ & Cumulative \% \\
\hline Kindergarten Teacher & 73 & 13.4 & 13.4 \\
\hline Elementary School Teacher & 48 & 8.8 & 22.2 \\
\hline Subject Teacher & 94 & 17.3 & 39.5 \\
\hline Vocational Teacher & 13 & 2.4 & 41.9 \\
\hline Pedagogue/other Professional Team Expert & 19 & 3.5 & 45.4 \\
\hline Non-Pedagogical Professions & 297 & 54.6 & 100 \\
\hline total & 544 & 100 & \\
\hline
\end{tabular}

\subsection{Measuring Instrument}

Table 2. Explained Variance and Saturation of the Components of the PSOC Scale

\begin{tabular}{|c|c|c|c|}
\hline $\mathrm{f}$ & Items & F1 & F2 \\
\hline \multirow{9}{*}{ 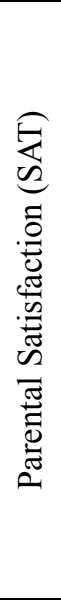 } & 3. I do not know what it is, but sometimes when I'm supposed to be in control, I feel & .71 & \\
\hline & 9. Being a parent makes me tense and anxious. & .71 & \\
\hline & $\begin{array}{l}\text { 1. Even though being a parent is rewarding, I am frustrated now while my child is at his/her } \\
\text { present age. }\end{array}$ & .70 & \\
\hline & $\begin{array}{l}\text { 2. I go to bed the same way I wake up in the morning, feeling I have not accomplished a whole } \\
\text { lot. }\end{array}$ & .69 & \\
\hline & 6. Sometimes I feel I am not getting anything done. & .59 & \\
\hline & 7. My talents and interests are in other areas, not in being a parent. & .58 & \\
\hline & 4. My mother/father was better prepared to be a good mother/father than I am. & .55 & \\
\hline & $\begin{array}{l}\text { 5. A difficult problem in being a parent is not knowing whether you are doing a good job or a } \\
\text { bad one. }\end{array}$ & .55 & \\
\hline & $\begin{array}{l}\text { 8. If being a mother/father of a child were only more interesting, I would be motivated to do a } \\
\text { better job as a parent. }\end{array}$ & .53 & \\
\hline \multirow{9}{*}{ 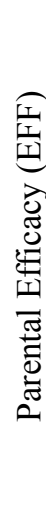 } & 16. I honestly believe I have the skills necessary to be a good mother/father to my child. & & .74 \\
\hline & 13. I meet my own personal expectations for expertise in caring for my child. & & .70 \\
\hline & 14. If anyone can find the answer to what is troubling my child, I am the one. & & .69 \\
\hline & 15. Considering how long I have been a mother/father, I feel thoroughly familiar with this role. & & .67 \\
\hline & $\begin{array}{l}\text { 11. I would make a fine model for a new mother/father to follow in order to learn what she/he } \\
\text { would need to know in order to be a good parent. }\end{array}$ & & .65 \\
\hline & 17. Being a good mother/father is a reward in itself. & & .57 \\
\hline & $\begin{array}{l}\text { 10. The problems of taking care of a child are easy to solve once you know how your actions } \\
\text { affect your child, an understanding I have acquired. }\end{array}$ & & .54 \\
\hline & 12. Being a parent is manageable, and any problems are easily solved. & & .52 \\
\hline & $\begin{array}{r}\text { Cronbach } \alpha \\
\text { total \% of explained variance }\end{array}$ & $\begin{array}{l}0.809 \\
42.43 \%\end{array}$ & 0.798 \\
\hline
\end{tabular}


For the purpose of this research The Parenting Sense of Competence scale (PSOC, Gibaud-Wallston \& Wandersman, 1978, quoted in Johnston \& Mash, 1989) was used to identify the self-assessment of parental Satisfaction and Efficacy. Prior to the analysis of set hypotheses, the validity and reliability of the questionnaire was tested.

Constructive validity of the PSOC scale was verified by the basic components method, and the internal consistency of the gained subscales or scale reliability was calculated using the Cronbach alpha coefficient. The questionnaire contains 17 statements and it is composed as a Likert type scale where respondents, on a scale of 1 -"completely agree" to 6 - "do not agree at all", state to what extent they agree with each statement. Eight items were inversely scored (items 10 to 17) to make the higher score equal greater experience. The basic components method with Varimax rotation examined the factor structure of the scale and two factors were extracted that explained the $42.43 \%$ of the total variance. Reliability of the type of the internal consistency subscale of self-assessment of parental role efficacy was calculated using the Cronbach alpha coefficient and it was found that for the subscale of parental satisfaction (SAT) it was 0.809 , and for the subscale of parental efficacy $(E F F)$ it was 0.798 . The obtained values are similar to the above results and can be considered high. Factor saturation and reliability of the type of internal consistency are shown in Table 2. Although Rogers and Matthews (2004) and Gilmore and Cuskelly (2009) accepted the three-factor structure, in which the third factor next to Satisfaction and Efficacy was named Interest, and was evaluated higher than the other two factors and did not necessarily correlate with them (Rogers \& Matthews, 2004), a two-factor structure was extracted in this research. Such a structure is more similar to that obtained by Johnston and Mash (1989) and Ohan et al. (2000, quoted in Rogers \& Matthews, 2004; Gilmore \& Cuskelly, 2009), allowing a conclusion about the stability of the two-component solution and the satisfactory constructional validity of the instrument. The two sub-scales are defined as parental satisfaction (SAT) and parental efficacy (EFF).

\section{Results}

It is possible to conclude that parents, in general, are satisfied with their parental role. That can be seen from their statements about the motivation for their role $(\mathrm{M}=5.621, \mathrm{SD}=.6508)$, high affinity for parental role $(\mathrm{M}=5.225$, $\mathrm{SD}=.896)$ and better preparedness for their role than their parents $(\mathrm{M}=5.118, \mathrm{SD}=.865)$. Parents exhibit greater insecurity when it comes to assessing efficacy or estimating claims that being a parent is manageable, and any problems are easily solved $(\mathrm{M}=3.103, \mathrm{SD}=1.094)$, and that they would make a fine model for a new mother/father to follow in order to learn what she/he would need to know in order to be a good parent $(\mathrm{M}=3.155, \mathrm{SD}=1.049)$ and that a difficult job in being a parent is not knowing whether you are doing a good job or a bad one (M=3.242, $\mathrm{SD}=1.2618)$.

After the parenting experience was established, the main hypothesis $(\mathrm{Hg})$ was tested as it assumed that there was no statistically significant difference in the self-assessment of parental competence between parents of pedagogical and non-pedagogical professions. In order to test the set hypothesis we looked whether there is a difference in results on the subscales of self-assessment of parental competence among parents of pedagogical and non-pedagogical professions. In this regard, the first hypothesis (H1) states that there is no statistically significant difference in the self-assessment of parental satisfaction between parents of pedagogical and non-pedagogical professions and the second hypothesis (H2) states that there is no statistically significant difference in self-assessment of parental efficacy between parents of pedagogical and non-pedagogical professions.

Parental satisfaction is associated with the satisfaction with the relationship the parents have with their child, but also the sense of satisfaction with themselves as parents (Sabatelli \& Waldron, 1995; Waldron-Hennessey \& Sabatelli, 1997). In this research, satisfaction was measured by the degree in which a parent feels frustrated, anxious or unmotivated in their role (Johnston \& Mash, 1989). Parental efficacy is defined as the degree in which a parent feels competent and capable to solve a problem with the child, and measures the degree in which the parent estimates that they have sufficient knowledge and ability to deal with everyday challenges of parenting (Johnston \& Mash, 1989).

The results show that although the respondents feel satisfied and effective in their parenting, they had a better estimate on the satisfaction than on the efficacy scale (shown in Table 3). Analysing the results of parenting in regard to their profession with the t-test for large samples, it was found that parents of pedagogical professions estimated their parental efficacy better than the parents of non-pedagogical professions (t-test, Mped $=4.091, \mathrm{SD}=0.643$, Mnped $=3.982, \mathrm{SD}=0.711, \mathrm{t}=1.866, \mathrm{df}=542, \mathrm{p}=0.063$ ). Since the difference is small, but still indicates a possible statistical significance, variance analysis was started. This process was chosen because the sample of pedagogical workers was divided into two sub-samples, the sub-sample of parents who were by profession kindergarten and elementary school teachers and sub-sample of parents who were by profession subject teachers, so the whole sample consisted of three sub-samples. By analysing variance for independent samples with Tuckey's Post Hoc Test, a 
statistically significant difference in self-assessment of parental competence was confirmed. The results show that parents who are by profession kindergarten and elementary school teachers, more than parents who are subject teachers and work in other professions, experience greater efficacy in their parenting (ANOVA, $\mathrm{F}=6.328, \mathrm{df}=2.541$, $\mathrm{p}=0.002$ ). In assessing parenting satisfaction, there was no statistically significant difference between parents divided into three sub-samples.

Table 3. Parents' Assessment of Parental Competence with Regard to Their Occupations Divided into Three Categories (kindergarten teachers/elementary school teachers, elementary and high school subject teachers/professors and non-pedagogical professions)

\begin{tabular}{|c|c|c|c|c|c|c|c|}
\hline Subscales & Parents' professions & & $\mathrm{N}$ & $\mathrm{M}$ & SD & $\mathrm{F}(\mathrm{df})$ & $\mathrm{p}$ \\
\hline \multirow{4}{*}{ 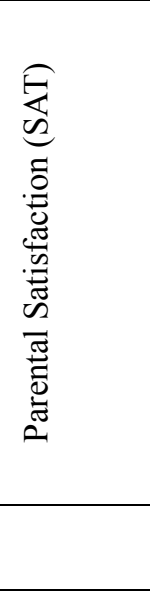 } & $\begin{array}{l}\text { Kindergarten and } \\
\text { Elementary School Teachers }\end{array}$ & $\begin{array}{l}\text { elementary and high school } \\
\text { subject teachers, } \\
\text { non-pedagogical } \\
\text { professions }\end{array}$ & 140 & 4.773 & 0.528 & \multirow[t]{4}{*}{$\begin{array}{l}1.725 \\
(2.541)\end{array}$} & \multirow[t]{4}{*}{0.179} \\
\hline & $\begin{array}{l}\text { Elementary and High School } \\
\text { Subject Teachers }\end{array}$ & $\begin{array}{l}\text { kindergarten and } \\
\text { elementary school teachers, } \\
\text { non-pedagogical } \\
\text { professions }\end{array}$ & 107 & 4.657 & 0.668 & & \\
\hline & $\begin{array}{l}\text { Non-Pedagogical } \\
\text { Professions }\end{array}$ & $\begin{array}{l}\text { kindergarten and } \\
\text { elementary school teachers, } \\
\text { elementary and high school } \\
\text { subject teachers }\end{array}$ & 297 & 4.654 & 0.691 & & \\
\hline & \multicolumn{2}{|r|}{ total } & 544 & 4.685 & 0.649 & & \\
\hline \multirow{4}{*}{ 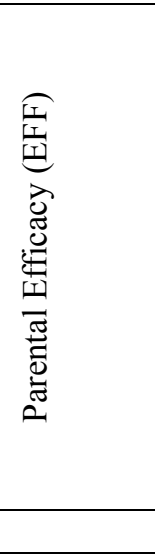 } & $\begin{array}{lr}\text { Kindergarten } & \text { and } \\
\text { Elementary } & \text { School } \\
\text { Teachers* } & \end{array}$ & $\begin{array}{l}\text { elementary and high school } \\
\text { subject teachers, } \\
\text { non-pedagogical } \\
\text { professions }\end{array}$ & 140 & $4.205^{*}$ & 0.646 & \multirow[t]{4}{*}{$\begin{array}{l}6.382 \\
(2.541)\end{array}$} & \multirow[t]{4}{*}{0.002} \\
\hline & $\begin{array}{l}\text { Elementary and High School } \\
\text { Subject Teachers }\end{array}$ & $\begin{array}{l}\text { kindergarten and } \\
\text { elementary school teachers, } \\
\text { non-pedagogical } \\
\text { professions }\end{array}$ & 107 & 3.942 & 0.610 & & \\
\hline & $\begin{array}{l}\text { Non-Pedagogical } \\
\text { Professions }\end{array}$ & $\begin{array}{l}\text { kindergarten and } \\
\text { elementary school teachers, } \\
\text { elementary and high school } \\
\text { subject teachers }\end{array}$ & 297 & 3.982 & 0.711 & & \\
\hline & & total & 544 & 4.031 & 0.682 & & \\
\hline
\end{tabular}

$* \mathrm{p}<0.05$; significantly higher result than the first and second groups

The obtained data was the cause for a deeper understanding of parental efficacy. Although the difference in the total factor has been shown, by a more detailed item analysis it was found that kindergarten and elementary school teachers, more than parents of other pedagogical professions and parents of non-pedagogical professions agree with the statement that if a parent thinks that "the problems of taking care of a child are easy to solve once you know how your actions affect your child, an understanding I have acquired" (ANOVA, F=6.328, $\mathrm{df}=2.541, \mathrm{p}=0.002$ ) and that "I would make a fine model for a new mother/father to follow in order to learn what she/he would need to know in order to be a good parent" (ANOVA, $\mathrm{F}=5.556, \mathrm{df}=2.539, \mathrm{p}=0.004$ ). Perhaps these two variables best indicate that the experience of parental efficacy can be related to the experience of knowledge about child care, but also the level of awareness of parents about how their behaviours can affect child development.

Given the obtained results it is possible to say that the hypothesis ( $\mathrm{Hg})$ has been partially confirmed.

\section{Discussion}

Parental competence can be explained as a set of different behaviours that encourage child development (Sanders, 1999). Čudina-Obradović and Obradović (2006) explain parental experience as a whole range of different 
characteristics from transition to parenting, redefinition of personal goals and values, experience of personal value because of the effort invested in child development and building the relationship with the child. In this process, the parent can evaluate how successful they are in dealing with commitments and challenges of parenting. It can best be described with the degree in which they feel satisfaction and efficacy in their parenting. Therefore, in this research, the self-assessment of satisfaction and efficacy of parents has been conducted.

Parental experience will depend on many factors, and recent researchers (Lambert et al., 2006; Stevanovic \& Rupert, 2009; Grandey \& Cropazano, 1999) found that for the experience of parental competence both general and professional competencies of individuals are important. Due to the insufficient number of research that could give a better understanding of the relationship between parental competence and professional pedagogical competencies, the assumption $(\mathrm{Hg})$ that there is no statistically significant difference in the parenting sense of competence between parents of pedagogical and non-pedagogical professions has been investigated.

The results show that there is no statistically significant difference between parents of pedagogical and non-pedagogical professions in assessing parenting satisfaction, and that both sub-samples of parents equally, and we can conclude highly, evaluate the satisfaction with their parenting. A high assessment of parental satisfaction was expected because parents who have participated in this research are highly educated, and the higher level of education of parents is positively associated with higher parental satisfaction. An explanation of this connection can be found in the fact that higher education can provide a higher socioeconomic status and a higher level of life quality which can reflect on the experience of satisfaction in different aspects of life (Glaeser, 2001, Healy, 2001, quoted in Yakovlev \& Daniels-Leguizamon, 2012). The higher level of education is also associated with a higher level of knowledge of child development, and this knowledge is considered to be the basis for the development of parental competence and a sense of self-confidence in the parental role (Morawska et al., 2008). Mothers who demonstrate a higher level of self-confidence, level of knowledge of child development, and knowledge of parental skills have had better relationships and interaction with their children (Morawska et al., 2008; Hurlbut \& McDonald, 1997).

Another factor which seems to be important in the experience of parenting satisfaction is the age of the child. Such results are in accordance with the results that show that parents are most satisfied with parenting during the younger age of the child, while they are less satisfied during the adolescent age (Lowenthal et al., 1975, Pasley \& Gecas, 1984, Veroff \& Feld, 1970, quoted in Waldron-Hennessey and Sabatelli, 1997). Parents who have at least one child between the age of three and seven participated in this research, so their subjective experience of high level of parenting satisfaction can also be associated with that characteristic.

Since research showed that professions of university professors, psychotherapists and social workers (Grandey \& Cropanzano, 1999; Lambert et al., 2006; Stevanovic \& Rupert, 2009) have shown greater parenting satisfaction, it can be said that parents' professions may also reflect on their parenting satisfaction. Due to the similarities between some duties among parents of pedagogical professions, it could be expected that the satisfaction assessment would be greater among these parents. However, in this research the results show a difference, but not a statistically significant one. It is possible to assume that when it comes to the subjective experience of parenting, the parents of pedagogical professions will not experience greater satisfaction with that role than the parents of other professions. This can be explained by the fact that the experience of satisfaction can be associated with an emotional character, perhaps more than with cognitive, but it remains a stimulus for further research of that variable.

Unlike the experience of satisfaction, the difference in self-assessment of efficacy between parents of pedagogical professions (kindergarten and elementary school teachers), other pedagogical professions (subject teachers and professors), and parents of non-professional occupations has been confirmed. Parents who are kindergarten and elementary school teachers considerably better evaluate their own parenting efficacy than the parents of other professions.

Results that show that there is a statistically significant difference in the self-assessment of efficacy between the parents of pedagogical and non-pedagogical professions are in favour of the assumption that pedagogical competencies, which are acquired through pedagogical education and developed by pedagogical practice, are closely related to parents' pedagogical competence, or more precisely related to the experience of parental efficacy. Although the level of education is positively related to the level of knowledge about parenting (Baranowski, Schilmoeller \& Higgins, 1990; Lacković-Grgin, 2011; Morawska et al., 2008), and it could have been expected that there will be no difference between parents, it is possible to conclude that professional pedagogical competencies of kindergarten and elementary school teachers nevertheless contribute to greater knowledge on parenting. First of all, this means that those parents have more knowledge about how their behaviour can affect the child, which can help them in solving problems with children more easily. Knowing how our behaviour can affect others can be closely related to the 
experience of trust in ourselves and our actions. If a person believes in themselves and their actions, they can provide a good model for children and other parents. Being a good model for children and their parents is an essential professional feature of pedagogical staff. Perhaps this is the fact that helps them overcome the obstacles to parenting. Furthermore, one more important feature of professional pedagogical activity is understanding the difference between engagement and involvement in child development (Goodall \& Ghent, 2014). In examining parental efficacy, the importance of proper and timely parental involvement, engagement, and childhood development is emphasized, as opposed to participation that can be considered a lower level of parental involvement in child development. Also, proper involvement of parents does not include "performativity" (Smith, 2010, p. 357) which can be considered as obsession with effectiveness (Smith, 2010).

The obtained results that show that pedagogical staff of certain professions feel more effective in their parenting role than other parents, suggest that work roles in which employees are required to actively and autonomously participate in the workplace may spill over on behaviours in the parental role. Specific behaviour in the workplace assumes a certain pattern of behaviour that can then be attributed to behaviour in parenting (Greenhaus \& Beutell, 1985; Lambert et al., 2006; Prottas \& Hyland, 2011; Stevanovic \& Rupert, 2009), and this research confirmed that there is a some sort of educational spillover (Crouter, 1984) from the professional role of kindergarten and elementary school teachers to parenting. Such a result can be an incentive for further research and a deeper understanding of the relationship between pedagogical and parental competence, and skills that might be of importance for the parental competence development. Furthermore, they can be an incentive to explore the spillover between pedagogical work and parenting role, and interviews could be used to identify a subjective experience of wellbeing of the profession of kindergarten and elementary school teachers for the development of parental competence. In addition, future research should also examine the perception of children whose parents are pedagogical professionals about the quality of parenting of their parents. Research shows that the perception of children about their parents' parental competence does not always have to be in line with the parent's sense of parenting quality (Golden \& Farber, 1998).

\section{Conclusion}

In examining the differences in assessment of parental satisfaction and efficacy between parents of pedagogical and non-pedagogical professions, the difference was confirmed only in assessment of parental efficacy. This distinction becomes clearer when parents who are by profession kindergarten and elementary school teachers are excluded from the subsample of the pedagogical staff. The results show that kindergarten and elementary school teachers, more than parents of other professions, better assess their parental efficacy and associate it with the experience of knowledge of how parental activity can affect a child and because of that knowledge can be a good behaviour model for their children and other parents.

Kindergarten and elementary school teachers can have such attitudes due to the professional pedagogical competencies they need in their workplace with children of that age. These general, specific and professional competencies can help them create positive attitudes about themselves and their parenting. These results can be an indicator of the necessary knowledge and skills, also needed by parents of other professions for active child development guidance and true parenting engagement. This research can point out that parenting satisfaction cannot (or should not) be professionalized, but also that differences in parental efficacy experience can be a stimulus for further research and a deeper understanding of parental engagement in learning processes and experiences of their child.

\section{Notes}

Although new data has been obtained, the most of theoretical part of this paper was based on the doctoral dissertation of A. Mandarić Vukušić, (2016). Parental Competence and (Non)Pedagogical Professions. (Doctoral dissertation). Zagreb: Faculty of Humanities and Social Sciences, University of Zagreb.

\section{References}

Baranowski, M.D., Schilmoeller, G.L., \& Higgins, B.S. (1990). Parenting attitudes of adolescent and older mothers. Adolescence, 25(100), 781-790.

Belsky, J. (1984). The Determinants of Parenting: A Process model. Child Development, 55, 83-96. https://doi.org/10.2307/1129836

Belsky, J. (2008). Social-Contextual Determinants of Parenting. In Tremblay, R.E. , Boivin, M., Peters, R., \& De, V. 
(Eds.), Encyclopedia on Early Childhood Development (online). Montreal, Quebec: Centre of Excellence for Early Child Development and Strategic Knowledge Cluster on Early Child Development. Retrieved from: http://www.child-encyclopedia.com/documents/BelskyANGxp-Parenting.pdf.

Bennett, J., \& Grimley, L.K. (2001). Parenting in the Global Community: A Cross-Cultural/International Perspective. In M.J. Fine \& S.W. Lee (Eds.), Handbook of Diversity in Parent Education. The Changing Faces of Parenting and Parent Education (pp. 97-133). San Diego, London: Academic Press. https://doi.org/10.1016/B978-012256483-3/50006-X

Crnic, K.A., Gaze, C., \& Hoffman, C. (2005). Cumulative Parenting Stress Across the Preschool Period: Relations to Maternal Parenting and Child Behaviour at Age 5. Infant and Child Development, 14, 117-132. https://doi.org/10.1002/icd.384

Crouter, A.C. (1984). Spillover From Family to Work: The Neglected Side of the Work-Family Interface. Human Relations, 37(6), 425-442. https://doi.org/10.1177/001872678403700601

Čudina-Obradović, M., \& Obradović, J. (2006). Psihologija braka i obitelji [Psychology of Marriage and Family]. Zagreb: Golden marketing - tehnička knjiga.

Gilmore, L. A., \& Cuskelly, M. (2008). Factor structure of the parenting sense of competence scale using a normative sample. Child Care, Health and Development, 38(1), 48-55.

Golden, V., \& Farber, B. A. (1998). Therapists as parents: Is it good for the children? Professional Psychology: Research and Practice, 29(2), 135-139. https://doi.org/10.1037/0735-7028.29.2.135

Goodall, J., \& Ghent, K. (2014). Parental belief and parental engagement in children's learning. British Journal of Religious Education, 36(3), 332-352. Retrieved from: http://dx.doi.org/10.1080/01416200.2013.820168.

Gorgievski, M.J., \& Hobfoll, S.E. (2008). Work Can Burn Us Out or Fire Us Up: Conservation of Resources in Burnout and Engagement. In R.B.J. Halbesleben (Ed.), Handbook od Stress and Burnout in Health Care (pp. 1-17). Nova Science Publisher, Inc.

Grandey, A.A., \& Cropanzano, R. (1999). The Conservation of Resources Model Applied to Work-Family Conflict and Strain. Journal of Vocational Behavior, 54, 350-370. https://doi.org/10.1006/jvbe.1998.1666

Greenhaus, J. H., \& Beutell, N. J. (1985). Sources and conflict between work and family roles. Academy of Management Review, 10, 76-88.

Hawk, C.K., \& Holden, G.W. (2006). Meta-Parenting: An Initial Investigation into a New Parental Social Cognition Construct. Parenting: Science and Practice, 6(4), 21-42. https://doi.org/10.1207/s15327922par0604_3

Hurlbut, N.L., \& McDonald, A. (1997). Adolescent mothers' self-esteem and role identity and their relationship to parenting skills knowledge. Adolescence, 32(127), 639-651.

Johnston, C., \& Mash, E.J. (1989). A Measure of Parenting Satisfaction and Efficacy. Journal of Clinical Child Psychology, 18(2),167-175. https://doi.org/10.1207/s15374424jccp1802_8

Kurz, R., \& Bartram, D. (2002). Competency and Individual Performance: Modeling the World of Work. In I.T. Robertson, M. Callinan \& D. Bartram (Eds.), Organizational Effectiveness: The Role of Psychology. John Wiely \& Sons, Ltd., Chichester, Uk. https://doi.org/10.1002/9780470696736.ch10.

Lacković-Grgin, K. (2011). Doživljaj i praksa roditeljstva u različitim životnim razdobljima [The Experience and Practice of Parenting in Different Periods of Life]. Društvena istraživanja, 4(114), 1063-1083. https://doi.org/10.5559/di.20.4.07

Lambert, E.G., Pasupuleti, S., Cluse-Tolar, T., Jennings, M., \& Baker, D. (2006). The Impact of Work-Family Conflict on Social Work and Human Service Worker Job Satisfaction and Organizational Commitment: An Exploratory Study. Administration in Social Work, 30(3), 55-74. https://doi.org/10.1300/J147v30n03_05

Laskey, B.J., \& Cartwright-Hatton, S. (2009). Parental discipline behaviours and beliefs about their child: associations with child internalizing and mediation relationships. Child: Care, Health and Development, 35, 717-727. https://doi.org/10.1111/j.1365-2214.2009.00977.x

Mandarić Vukušić A. (2016). Roditeljska kompetencija i (ne)pedagoška zanimanja [Parental Competence and (non)pedagogical Professions]. (Doctoral Dissertation). Zagreb: Faculty of Humanities and Social Sciences University of Zagreb.

Morawska, A., Winter, L., \& Sanders, M.R. (2008). Parenting Knowledge and its Role in the Prediction of 
Dysfunctional Parenting and Disruptive Child Behaviour. Child: Care, Health and Development, 35(2), 217-226. https://doi.org/10.1111/j.1365-2214.2008.00929.x

Prottas, D.J., \& Hayland, M.A.M. (2011). Is High Involvement at Work and Home So Bad? Contrasting Scarcity and Expansionist Perspectives. The Psychologist-Manager Journal, 14, 29-51. https://doi.org/10.1080/10887156.2011.546191

Ramaekers, S., \& Suissa, J. (2012). Contemporary Philosophies and Theories in Education, vol.4. The Claims of Parenting. Reasons, Responsibility and Society. London, New York: Springer Science + Business Media B.V.

Reić Ercegovac, I. (2011). Neki prediktori doživljaja roditeljstva majki i očeva djece dojenačke dobi [Some Predictors of the Parenting Experience in Mothers and Fathers of Toddlers]. Napredak, 152(2), 267-288.

Rogers, H., \& Matthews, J. (2004). The Parenting Sense of Competence Scale: Investigation of the Factor Structure, Reliability, and Validity for an Australian Sample. Australian Psychologist, 39(1), 88-96. https://doi.org/10.1080/00050060410001660380

Sabatelli, R.M., \& Waldron, R.J. (1995). Measurement Issues in the Assessment of the Experiences of Parenthood. Journal of Marriage and the Family, 57, 969-980. https://doi.org/10.2307/353416

Sanders, M.R. (1999). Triple P-Positive Parenting Program: towards an empirically validated multilevel parenting and family support strategy for the pervention of behavior and emotional problems in children. Clinical Child and Family Psychology Review, 2, 71-90. https://doi.org/10.1023/A:1021843613840

Secer, Z., Gülay Ogelman, H., Önder, A., \& Berengel, S. (2012). Analysing Mothers' Self-efficacy Perception towards Parenting in Relation to Peer Relationships of 5-6 year-old Preschool Children. Educational Sciences: Theory and Practice, 12(3), 2001-2008.

Smith, R. (2010). Total Parenting. Educational Theory, 60(3), 357-369. https://doi.org/10.1111/j.1741-5446.2010.00363.x

Stevanovic, P., \& Rupert, P.A. (2009). Work-Family Spillover and Life Satisfaction Among Professional Psychologists. Professional Psychology: Research and Practice, 40(1), 62-68. https://doi.org/10.1037/a0012527

Taris, T. W. (1999). The Mutual Effects Between Job Resources and Mental Health: A Prospective Study Among Dutch Youth. Genetic, Social, and General Psychology Monographs, 125(4), 433-450.

Waldron-Hennessey, R., \& Sabatelli, R.M. (1997). The Parental Comparision Level Index: Measure for Assessing Parental Rewards and Costs Relative to Expectations. Journal of Marriage and the Family, 59, 824-833. https://doi.org/10.2307/353785

Yakovlev, P., \& Daniels-Leguizamon, S. (2012). Ignorance is Not Bliss: On the Role of Education in Subjective Well-Being. Journal of Socio-Economics, 41(6), 806-815. https://doi.org/10.1016/j.socec.2012.08.009 